\title{
Global profiling of double stranded RNA- and IFN- $\gamma$-induced genes in rat pancreatic beta cells
}

\author{
J. Rasschaert ${ }^{1}$, D. Liu ${ }^{1}$, B. Kutlu ${ }^{1}$, A. K. Cardozo $^{1}$, M. Kruhøffer ${ }^{2}$, T. F. Ørntoft ${ }^{2}$, D. L. Eizirik ${ }^{1}$ \\ ${ }^{1}$ Laboratory of Experimental Medicine, Université Libre de Bruxelles, Brussels, Belgium \\ ${ }^{2}$ Molecular Diagnostic Laboratory, Department of Clinical Biochemistry, Aarhus University, Denmark
}

\begin{abstract}
Aims/hypothesis. Viral infections and local production of IFN- $\gamma$ might contribute to beta-cell dysfunction/ death in Type 1 Diabetes. Double stranded RNA (dsRNA) accumulates in the cytosol of viral-infected cells, and exposure of purified rat beta cells to dsRNA (tested in the form of polyinosinic-polycytidylic acid, PIC) in combination with IFN- $\gamma$ results in beta-cell dysfunction and apoptosis. To elucidate the molecular mechanisms involved in PIC + IFN- $\gamma$-effects, we determined the global profile of genes modified by these agents in primary rat beta cells.

Methods. FACS-purified rat beta cells were cultured for 6 or $24 \mathrm{~h}$ in control condition or with IFN- $\gamma$, PIC or a combination of both agents. The gene expression profile was analysed in duplicate by high-density oligonucleotide arrays representing 5000 full-length genes and 3000 EST's. Changes of greater than or equal to 2.5-fold were considered as relevant.

Results. Following a 6- or 24-h treatment with IFN- $\gamma$, PIC or IFN- $\gamma$ and PIC, we observed changes in the expression of 51 to 189 genes. IFN- $\gamma$ modified the expression of MHC-related genes, and also of genes in-
\end{abstract}

volved in beta-cell metabolism, protein processing, cytokines and signal transduction. PIC affected preferentially the expression of genes related to cell adhesion, cytokines and dsRNA signal transduction, transcription factors and MHC. PIC and/or IFN- $\gamma$ up-regulated the expression of several chemokines and cytokines that could contribute to mononuclear cell homing and activation during viral infection, while IFN- $\gamma$ induced a positive feedback on its own signal transduction. PIC + IFN- $\gamma$ inhibited insulin and GLUT-2 expression without modifying $p d x-1$ mRNA expression. Conclusion/interpretation. This study provides the first comprehensive characterization of the molecular responses of primary beta cells to dsRNA + IFN- $\gamma$, two agents that are probably present in the beta cell milieu during the course of virally-induced insulitis and Type 1 Diabetes. Based on these findings, we propose an integrated model for the molecular mechanisms involved in dsRNA + IFN- $\gamma$ induced beta-cell dysfunction and death. [Diabetologia (2003) 46:1641-1657]

Keywords Double stranded RNA, microarray analysis, apoptosis, pancreatic beta cells, interferon- $\gamma$, nitric oxide, NF- $\kappa \mathrm{B}$, diabetes mellitus.
Received: 3 July 2003 / Revised: 11 September 2003

Published online: 5 November 2003

(C) Springer-Verlag 2003

Corresponding author: J. Rasschaert, Laboratory of Experimental Medicine, Université Libre de Bruxelles, Route de Lennik, 808, CP 618, 1070 Brussels, Belgium

E-mail: jrasscha@ulb.ac.be

Abbreviations: AS, argininosuccinate synthetase; ADAR, RNAspecific adenosine deaminase; Bax, bcl-2 associated $\mathrm{x}$ protein; $\mathrm{BB}$ rats, diabetes-resistant BioBreeding rats; bcl-2, B-cell lymphoma/leukemia-2; BH3, bcl-2 homology domain-3; Bid, $\mathrm{BH} 3$ interacting domain death agonist; dsRNA, double stranded RNA; CCK, cholecystokinin; eIF2 $\alpha$, eukaryotic initiation factor $2 \alpha$; EMC-D, encephalomyocarditis virus; ER, endoplasmic reticulum; ESTs, expressed sequence tags; GADD, growth arrest and DNA damage; GAPDH, glyceraldehyde 3-phosphate dehydrogenase; GH, growth hormone; GIP, gastric inhibitory peptide; HMGCoA, 3-hydroxy 3-methylglutaryl coenzyme A; HO, heme oxygenase; hsp, heat shock protein; ICE, interleukin converting enzyme/caspase 1; IFN, interferon; IL, interleukin; iNOS, induc- ible nitric oxide synthase; IRF, interferon regulatory factor; JAK$1 / 2$, Janus tyrosine kinase 1 and 2; MAP, mitogen activated protein; MCP-1, macrophage chemoattractant protein-1; MHC, major histocompatibility complex; MIP, macrophage inflammatory protein; MnSOD, manganese superoxide dismutase; MX, myxovirus; NF, nuclear factor; NO, nitric oxide; NOD mouse, non obese diabetic mouse; MGMT, O-6-methylguanine-DNA methyltransferase; OAS, 2',5'-oligoadenylate synthetase; PC, prohormone convertase; PDX-1, pancreatic duodenal homeobox factor1; PI, propidium iodide; PIC, polyinosinic-polycytidylic acid; PKR, dsRNA dependent protein kinase; RANTES, regulated upon activation, normal T-cell expressed, and presumably secreted; SERCA-2, sarco(endo)plasmic reticulum $\mathrm{Ca}^{+2}$ ATPase type 2; STAT, signal transducers and activators of transcription; T1DM, type 1 diabetes mellitus; TLR, toll-like receptor.

J. Rasschaert and D. Liu contributed equally to the article

Electronic Supplementary Material

Supplementary material is available in the online version of this article at http://dx.doi.org/10.1007/s00125-003-1245-y 
Type 1 diabetes mellitus is an auto-immune disease associated with a progressive and selective destruction of the insulin-producing pancreatic beta cells $[1,2]$. Although a genetic susceptibility seems to be a prerequisite for the development of Type 1 Diabetes [3, 4], it is now clear that environmental factors such as viral infections are also important aetiological determinants $[2,5]$.

There is extensive epidemiological evidence for the involvement of viral infections in the pathogenesis of Type 1 Diabetes [6]. Up to now, 13 different viruses, most of them belonging to the enterovirus family, have been found to be associated with the onset of Type 1 Diabetes in humans and in various animal models [7]. Different mechanisms have been proposed for the role of viruses in the pathogenesis of Type 1 Diabetes. These include: (i) infection and rapid destruction of beta cells [8]; (ii) triggering of local inflammation, leading to destruction of the beta cells through the production of NO, cytokines and other immune mediators in a mechanism referred to as "innocent bystander killing" $[9,10]$; (iii) molecular mimicry, based on a partial sequence homology between a protein of the infected cells (i.e. GADD65) and a viral antigen, leading to autoimmune destruction of the beta cell [11]; (iv) viral infection, coupled with one or more of the factors described above, acting in conjunction to induce beta cell death [12]. For example, mouse infection with a high titre of the $\mathrm{D}$ variant of the encephalomyocarditis (EMC-D) virus leads to beta-cell destruction and diabetes mainly as a result of viral replication within beta cells, while mouse infection with a low titre of EMC-D virus leads to diabetes as a chronic process, caused by the destruction of beta cells by soluble mediators such as IL- $1 \beta$, TNF- $\alpha / \beta$ and NO produced by macrophages or the beta cells themselves [7].

The molecular mechanisms involved in beta cells damage by viruses, alone or in combination with soluble mediators, remain to be elucidated. During viral infection, accumulation of the viral replicative intermediate double stranded RNA (dsRNA) in the cytosol of the infected cell stimulates antiviral activities, such as dsRNA-dependent protein kinase (PKR) activation, type I interferons and NO production and a general inhibition of protein translation $[13,14]$. These antiviral responses can be mimicked by treatment of cells with the synthetic dsRNA polyinosinic-polycytidylic acid (PIC) $[15,16]$. PIC triggers the development of hyperglycaemia in diabetes-resistant BioBreeding (BB) rats and accelerates the development of the disease in diabetes-prone $\mathrm{BB}$ rats $[17,18]$. In vitro, PIC inhibits glucose-stimulated insulin biosynthesis in mouse islets [19] and when used in combination with IFN- $\gamma$ affects rat islet cell function and viability by a mechanism involving, at least in part, increased inducible nitric oxide synthase (iNOS) expression and NO production $[20,21]$.
We have previously shown that exposure of fluorescence-activated cell sorting-(FACS)-purified rat beta cells to PIC alone does not induce cell death. However, when these cells are exposed to PIC + IL- $1 \beta$ or PIC + IFN- $\gamma$ they die mostly by apoptosis. The mechanisms of death induction are either NO-dependent in the case of PIC + IL-1 $\beta$, or NO-independent, in the case of PIC + IFN- $\gamma$ [21]. Moreover, PIC regulates the expression of several genes that could participate in the induction of islet inflammation and beta-cell death, such as Fas, iNOS, IL-15 and diverse chemokines $[21,22]$. The complete range of genes induced by PIC and cytokines in pancreatic beta cells remains, however, to be clarified.

Evaluation of complex patterns of gene expression is now feasible by the use of microarray analysis [23]. We have previously used high-density oligonucleotide arrays to analyse FACS-purified rat beta cells exposed for 6 or 24 h to IL-1 $\beta+\operatorname{IFN}-\gamma[24,25]$. Based on the findings obtained, we proposed that beta-cell fate following cytokines exposure, namely death by apoptosis or survival with or without complete functional recovery, depends on the intricate pattern of dozens of genes up- or down-regulated in parallel and/or sequentially. Moreover, these and subsequent data on INS-1 cells [26] allowed us to start an annotated "Beta Cell Gene Bank", including information on nearly 3000 genes expressed in beta cells and in INS-1 cells, of which 700 are modified by cytokines. Against this background, we carried out a microarray analysis of FACS-purified rat pancreatic beta cells exposed for 6 or $24 \mathrm{~h}$ to PIC, IFN- $\gamma$ or a combination of both agents. The data obtained provide the first broad picture on how a primary beta cell responds to dsRNA and the inflammatory cytokine IFN- $\gamma$, an experimental condition which bears similarity to the in vivo situation during the course of a viral infection. The results obtained allowed us to propose a comprehensive hypothesis for the mechanisms involved in dsRNA and IFN- $\gamma$ induced beta-cell dysfunction and death.

\section{Materials and methods}

Islet cell isolation and culture. Pancreatic islets were isolated from 10-12-week-old male Wistar rats by collagenase digestion, and subsequently dissociated into single cells in a calcium-free medium containing dispase $(0.5 \mathrm{mg} / \mathrm{ml})$. Single betacells were purified by autofluorescence-activated cell sorting (FACS) [27]. These preparations contain around 90-95\% viable beta cells [data not shown, 27]. The purified beta cells were cultured in HAM's F-10 medium (Invitrogen, Paisley, Scotland) supplemented with $10 \mathrm{mmol} / \mathrm{l}$ glucose [28]. For determination of viability, FACS-purified single beta cells $\left(10^{4}\right.$ cells per well) were cultured for 6 days in Falcon 96-well microtitre plates (Becton Dickinson, New Jersey, N.J., USA) pre-coated with poly-L-lysine and containing $200 \mu \mathrm{l}$ of medium. Culture medium was changed every 3 days and fresh IFN- $\gamma$ or PIC was added. For RNA extraction for microarray or RT-PCR analysis, single beta cells were re-aggregated for $3 \mathrm{~h}$ 
in a rotatory shaking incubator [29], cultured for 14-16 h in suspension, and then exposed for 6 or $24 \mathrm{~h}$ to IFN- $\gamma$ (1000 U/ml; $10 \mathrm{U} / \mathrm{ng}$; Invitrogen) or PIC (100 $\mu \mathrm{g} / \mathrm{ml}$; Sigma Chemical, St Louis, Mo., USA). In some experiments, recombinant human IL-1 $\beta(50 \mathrm{U} / \mathrm{ml}, 38 \mathrm{U} / \mathrm{ng}$, a kind gift of Dr. C.W. Reynolds from the National Cancer Institute, Bethesda, Md., USA) was also utilized as a positive control. The concentrations of cytokines and PIC, and the time points for array analysis, were selected based on our previous studies in beta cells [21, 22, 24, 25], and aimed to analyse beta cells at time points which precede non-specific changes in mRNA expression induced by early apoptosis. Culture media were collected after $24 \mathrm{~h}$ for nitrite determination (nitrite is a stable product of $\mathrm{NO}$ oxidation), which was done spectrophotometrically at $546 \mathrm{~nm}$ wavelength after coloured reaction with the Griess reagent [30].

Assessment of beta cell protein synthesis and viability. Total protein biosynthesis was determined at $10 \mathrm{mmol} / \mathrm{l}$ glucose using $\mathrm{L}-\left[4,5-{ }^{3} \mathrm{H}\right]$ leucine incorporation and trichloroacetic precipitation [31]. The experiments were carried out in duplicate, using $6 \times 10^{4}$ re-aggregated beta cells per condition. The cells were exposed for 1,5 and $23 \mathrm{~h}$ to IFN- $\gamma$ + PIC (same concentrations as described above) or left untreated (control) before determination of protein biosynthesis for $2 \mathrm{~h}$ in the absence (control) or presence of IFN- $\gamma+$ PIC. These time points were selected to cover an early time point $(3 \mathrm{~h})$, and then two time points placed $1 \mathrm{~h}$ after the time points used for microarray analysis ( 6 and $24 \mathrm{~h}$ ), the rationale being that protein synthesis usually lags behind mRNA expression. As a positive control for protein biosynthesis inhibition, some control cells were exposed to cycloheximide $(10 \mu \mathrm{mol} / \mathrm{l})$ during the final $2 \mathrm{~h}$ of the incubation period.

The percentage of viable, apoptotic and necrotic beta cells was determined after 6 days exposure to IFN- $\gamma$ and/or PIC [21, 22]. For this purpose, beta cells were incubated for $15 \mathrm{~min}$ with propidium iodide (PI, $10 \mu \mathrm{g} / \mathrm{ml}$ ) and Hoechst (HO) 342 $(10 \mu \mathrm{g} / \mathrm{ml})$ [32]. This fluorescence assay for single beta cells is quantitative and has been validated by systematic comparisons with electron microscopy observations [32, 33]. The method has been successfully used to evaluate apoptosis/necrosis in rat $[21,22,32]$, mouse $[34,35]$ and human [36] beta cells.

Microarray analysis. For microarray analysis, total RNA was isolated from beta cells (at least $10 \mu \mathrm{g} / \mathrm{sample}$ ) and used to prepare biotinylated cRNA. The labelled cRNAs were hybridized in duplicate to the rat U34-A oligonucleotide array (Affymetrix, Santa Clara, Calif., USA) [24, 25]. Due to difficulties in obtaining a sufficient number of primary beta cells in a single isolation, and to decrease putative biases caused by biological variation, the cells were pooled from four independent experiments, using in each experiment $3.5-3.7 \times 10^{5}$ cells/group. We have shown before that microarray analysis, carried out in duplicate on pooled beta cell samples, provides a reliable estimation of massive changes in mRNA expression, as confirmed by a greater than $90 \%$ confirmation by RT-PCR of genes observed as modified in the array [24, 25, 37, present data]. Analysis of differential expression was carried out using the GeneChip Suite software, version 4.0.1 (Affymetrix, Santa Clara, Calif., USA). Arrays were normalized by global scaling, with the arrays scaled to an average intensity of 150 . Genes were considered as modified by PIC and/or IFN- $\gamma$ in case they fulfilled the following criteria [24, 25]: (i) the mRNA was present in either control or cells exposed to PIC and/or IFN- $\gamma$ in both duplicates; (ii) the mean average fold change (experimental group vs control) was greater than or equal to 2.5 ; (iii) the fold change in each individual duplicate was greater than or equal to 2.0. We have used our own curated "Beta Cell Gene Bank" to assign the filtered genes into their respective functional clusters. The expressed sequence tags (ESTs) that had homology to a known sequence were annotated using the Resourcerer 6.0 database [38]. Non-identified ESTs are not shown here.

RT-PCR and real time RT-PCR. RT-PCR was done using poly(A)+ RNA as described [24]. The number of cycles was selected to allow linear amplification of the cDNA under study. The primer sequences used for amplification of rat cDNAs for GAPDH, GADD153 [24], $p d x-1$, GLUT-2 and c-Myc [25] and for sarco(endo)plasmic reticulum $\mathrm{Ca}^{2+}$ ATPase type 2 (also called SERCA-2) [39] were as described in the indicated references. For the other genes studied, the primer sequences and their respective PCR fragment lenghts were as follows: dsRNAdependent protein kinase (PKR), forward (5'-AATCACGCCAACATTGTTCA-3') and reverse (5'-CACCGGGTCTTGTATCGACT-3') (107 bp); RNA-specific adenosine deaminase (ADAR), forward (5'-AAGAAACAGGGCAAG-CAAGA-3') and reverse (5'-TGTTGGTCAGAGCGTTGAAG-3') (244 bp); CEBP/ $\beta$, forward (5'-CAAGCTGAGCGACGAG-TACA-3') and reverse (5'-CAGCTGCTCCACCTTCTTCT-3') (147 bp) and Bip/ GRP78, forward (5'-CTCAAAGAGCGCATTGACAC-3') and reverse (5'-GCCACTTGGGCTATAGCATT-3') (446 bp). The identity of the PCR fragments of each gene was confirmed by size after electrophoretic migration on ethidium bromide-stained agarose gels photographed under UV-transillumination using Kodak Digital Science DC120 camera (Kodak, Rochester, N.Y., USA). The data are shown as a representative figure for four similar experiments. Expression of the "housekeeping" gene GAPDH is not affected by exposure to cytokines in both whole islets and FACS-purified beta cells [21, 22, 40].

Real-time RT-PCR was done as described [41] using a Lightcycler instrument in a $20 \mu \mathrm{l}$ reaction containing $3 \mathrm{mmol} / \mathrm{l}$ $\mathrm{MgCl}_{2}, 0.5 \mu \mathrm{mol} / 1$ forward and reverse primers, $2 \mu \mathrm{l}$ FastStart SYBR Green mix (Roche), and $2 \mu$ template cDNA. The primer sequences and their respective PCR fragment lenghts were as follows: GADD153, forward (5'-CCAGCAGAGGTCACAAGCA- $\left.3^{\prime}\right)$ and reverse (5'-CGCACTGACCACTCTGTTTC$\left.3^{\prime}\right)$ (126 bp); SERCA-2, forward (5'-TTGTGGCCCGAAACTACCT-3') and reverse (5'-TTCATAATGAGCAGCACAAAGGG-3') (121 bp). The method used for quantification is the standard curve approach $[42,43]$. To obtain the standard curve, the primer sequences and their respective PCR fragment lenghts were as follows: GADD153, forward (5'-GTCTCTGCCTTTCGCCTTTG- $3^{\prime}$ ) and reverse (5'-CTACCCTCAGTCCCCTCCTC-3') (605 bp); SERCA-2, forward (5'-TCTAGTCACCATAGAGATGTG-3') and reverse (5'-TACTGACTGAGGTAGCAGGA-3') (912 bp).

Promoter studies. A plasmid construct containing the human $p d x-1$ gene promoter linked to a luciferase reporter gene was kindly provided by Dr D. Melloul, Department of Endocrinology, Hadassah University Hospital, Jerusalem, Israel [44]. Transfected beta cells were exposed to cytokines and/or PIC for $24 \mathrm{~h}$ (same concentrations as above). Luciferase activity was assayed with the Dual-Luciferase Reporter Assay System (Promega) as previously described [21, 41]. Test values were corrected for the luciferase activity value of the internal control plasmid, pRL-CMV.

Statistical analysis. Results of microarray analysis are shown as means of two similar determinations. The results for other experiments are presented as means \pm SEM of at least three independent experiments. Statistical differences between the groups were determined by paired Student's $t$-test or ANOVA, as indicated. A $p$ value of less than 0.05 was considered statistically significant. 


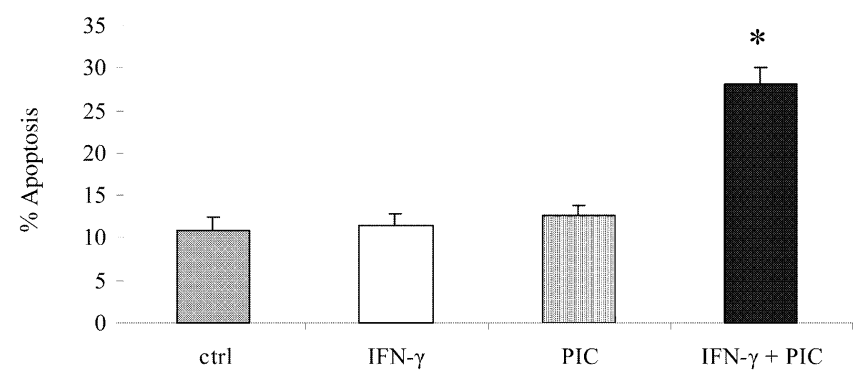

Fig. 1. Percentage of apoptosis observed in FACS purified beta cells exposed for 6 days to PIC $(100 \mu \mathrm{g} / \mathrm{ml})$ and/or IFN- $\gamma$ (1000 U/ml). Cell viability was determined with the DNAbinding dyes Hoechst 342 and PI. Data are means \pm SEM of six experiments. $* p<0.001$ vs. control, ANOVA

\section{Results}

Viability and nitrite production of beta cells exposed to PIC and/or IFN- $\gamma$. Exposure of FACS-purified beta cells to PIC and IFN- $\gamma$ for 6 days induced a significant $(p<0.001)$ increase in the percentage of apoptotic cells when compared against control cells. Neither the treatment with PIC nor with IFN- $\gamma$ alone led to betacell death, indicating a synergistic effect between PIC and IFN- $\gamma$ to induce beta-cell apoptosis (Fig. 1). We did not detect a significant increase in the percentage of necrotic cells (data not shown).

To identify by microarray analysis early and late IFN- $\gamma$ and/or PIC induced or decreased genes in pancreatic beta cells, the cells were exposed for 6 or $24 \mathrm{~h}$ to the following conditions: control condition; IFN- $\gamma$ (1000 U/ml); PIC (100 $\mu \mathrm{g} / \mathrm{ml})$; or the combination of both agents. When the beta cells were treated for $6 \mathrm{~h}$ with PIC and/or IFN- $\gamma$, there was no detectable nitrite production. However, after a $24-\mathrm{h}$ treatment the combination of PIC and IFN- $\gamma$ significantly increased nitrite production as compared to control, non-treated cells. Thus, the values for PIC + IFN- $\gamma$ were $5.6 \pm 1.1 \mathrm{pmol}$ nitrite $\cdot 10^{-3}$ cells.h (means \pm SEM; $n=6 ; p<0.05$ vs control) while control values were $0.7 \pm 0.4$ pmol nitrite $\cdot 10^{-3}$ cells $\cdot h$ (mean $\pm \mathrm{SEM} ; n=6$ ). When tested alone, neither PIC nor IFN- $\gamma$ affected nitrite production (data not shown). These data on viability and nitrite production are in good agreement with our previous observations $[21,22]$ and confirm that both IFN- $\gamma$ and PIC were biologically active.

Identification of IFN- $\gamma$ and/or PIC -modified genes in beta cells by microarray analysis. Cells from four separate experiments conducted as described above were pooled for RNA extraction, and the resulting biotinylated cRNAs were hybridized in duplicate to the Affymetrix rat U34-A oligonucleotide array containing about 8000 probes (77\% known genes and 23\% ESTs). Approximately 3759 (3300 to 4217) genes or ESTs were scored as present in each of the six condi-
Table 1. Total number of up- and down-regulated genes in rat pancreatic beta cells after 6 or $24 \mathrm{~h}$

\begin{tabular}{lccccc}
\hline & \multicolumn{2}{l}{$6 \mathrm{~h}$} & & $24 \mathrm{~h}$ & \\
\cline { 2 - 3 } \cline { 5 - 6 } & Increased & Decreased & & Increased & Decreased \\
\hline IFN- $\gamma$ & $25(28 \%)$ & $64(72 \%)$ & & $46(88 \%)$ & $6(12 \%)$ \\
PIC & $81(94 \%)$ & $5(6 \%)$ & & $54(95 \%)$ & $3(5 \%)$ \\
IFN- $\gamma+$ PIC & $130(80 \%)$ & $33(20 \%)$ & & $140(73 \%)$ & $51(27 \%)$ \\
TOTAL & $236(70 \%)$ & $102(30 \%)$ & & $240(80 \%)$ & $60(20 \%)$
\end{tabular}

IFN- $\gamma$ - and/or dsRNA-induced differences in gene expression were considered as present when the mean fold change of the duplicates was $\geq 2.5$, and both individual fold change values were $\geq 2.0$. Data are expressed in absolute numbers, or percentages (between parenthesis)

tions, in fair agreement with our previous observations $[24,25]$.

Following a 6-h exposure of beta cells to IFN- $\gamma$ or PIC we observed changes in the expression of respectively 89 and 86 genes, while exposure to PIC + IFN- $\gamma$ nearly doubled the number of modified genes (163 genes). A 24-h treatment induced a similar pattern, with 52-57 genes modified by IFN- $\gamma$ or PIC alone, and a nearly four-fold increase in the number of changed genes by the combination of IFN- $\gamma+$ PIC. Of note, except in the case of a 6-h exposure to IFN- $\gamma$, the majority (73-95\%) of these modifications in gene expression consisted in up-regulation (Table 1). The PIC and/or IFN- $\gamma$ responsive genes were clustered in 15 groups according to the putative biological function of their encoded proteins. Table 2 shows the percentages of affected genes observed in each experimental condition, expressed relative to the total number of modified genes. After treatment with IFN- $\gamma$ alone for $6 \mathrm{~h}$, the most frequent changes in gene expression were observed in beta-cell metabolism, protein processing and cytokine signal transduction. Of note, after 24-h exposure to IFN- $\gamma$, the MHC-related genes represented $31 \%$ of all modified genes. Exposure to PIC alone for 6 or $24 \mathrm{~h}$ affected preferentially the expression of genes related to cell adhesion, cytokine signal transduction, transcription factors and MHC. Beta-cell treatment with both IFN- $\gamma$ and PIC led to a combined pattern of the modifications described above, but several novel genes were detected as changed when cells were exposed to a combination of both agents.

From the 340 IFN- $\gamma$ and/or PIC modified genes, 161 genes of special relevance are presented in Table 3. The complete list of modified genes is presented in S1, deposited as "Supporting online material" at Diabetologia home page: http://dx.doi.org/10.1007/ s00125-003-1245 .

Among the metabolism-related genes, a decrease in the expression of mRNAs encoding for genes involved in glucose metabolism, such as the beta-cell specific glucose transporter GLUT-2 and lactate dehy- 
Table 2. Percentages of differentially expressed genes following a 6 or 24 h exposure to IFN- $\gamma$ and/or PIC

\begin{tabular}{|c|c|c|c|c|c|c|c|}
\hline & \multirow[t]{2}{*}{ Gene clusters } & \multicolumn{3}{|l|}{$6 \mathrm{~h}$} & \multicolumn{3}{|l|}{$24 \mathrm{~h}$} \\
\hline & & $\begin{array}{l}\text { IFN- } \gamma \\
\%\end{array}$ & $\begin{array}{l}\text { PIC } \\
\%\end{array}$ & $\begin{array}{l}\mathrm{IFN}-\gamma+\mathrm{PIC} \\
\%\end{array}$ & $\begin{array}{l}\mathrm{IFN}-\gamma \\
\%\end{array}$ & $\begin{array}{l}\text { PIC } \\
\%\end{array}$ & $\underset{\%}{\mathrm{IFN}-} \gamma+\mathrm{PIC}$ \\
\hline 1. & Metabolism & 13.5 & 5.8 & 12.1 & 11.8 & 5 & 15.3 \\
\hline 2. & Protein synthesis, modification and secretion & 12.4 & 8.1 & 7.9 & 13.7 & 5 & 7.4 \\
\hline 3. & Ionic channels, ions transporters and related proteins & 7.9 & 1.2 & 1.2 & 2 & 0 & 1.6 \\
\hline 6. & Cytokine processing and signal transduction & 14.6 & 12.8 & 13.9 & 9.8 & 10 & 11.6 \\
\hline 7. & MHC and related genes & 9 & 12.8 & 11.5 & 31.4 & 17 & 10.1 \\
\hline 8. & Cell adhesion and cytoskeleton & 9 & 12.8 & 9.7 & 2 & 15 & 6.9 \\
\hline 9. & Transcription factors and related genes & 5.6 & 11.6 & 11.5 & 9.8 & 15 & 13.2 \\
\hline 10. & RNA synthesis and splicing factors & 0 & 0 & 0 & 0 & 0 & 1.1 \\
\hline 11. & Cell cycle & 3.4 & 2.3 & 2.4 & 0 & 0 & 1.1 \\
\hline 15. & Total number of genes (absolute values) & 89 & 86 & 163 & 52 & 57 & 191 \\
\hline
\end{tabular}

IFN- $\gamma$ - and/or dsRNA-induced differences in gene expression were considered as present when the mean fold change of the duplicates was $\geq 2.5$, and both individual fold change values were $\geq 2.0$.

drogenase (isoforms A and B) was observed (Table 3; item 1.1). Interestingly, expression of glucokinase was not affected by any of the tested conditions. While expression of glycolytic enzymes was down-regulated, several genes involved or related to lipid metabolism, such as ATP-citrate lyase, 3-hydroxy-3 methylglutaryl-coenzyme A (HMGCoA) reductase, LDL receptor, mitochondrial cytochrome $\mathrm{P} 450$ and stearyl-CoA desaturase were up-regulated following exposure for 6 or 24 h to both IFN- $\gamma$ and PIC (Table 3, item 1.4). Of note, exposure to IFN- $\gamma$ and PIC led to modifications in key genes related to arginine metabolism and nitric oxide formation (Table 3, item 1.2). The modified genes are arginase (decreased), argininosuccinate synthetase, iNOS and the cationic amino acid transporter-1 (all increased) and correlate well with the observed increased production of nitrite after 24-h treatment by both agents (see above).

After 24-h treatment with IFN- $\gamma$ and PIC, there was down-regulation of mRNAs encoding mitochondrial subunits of respiratory chain genes involved in ATP production, such as NADH dehydrogenase and cytochrome b5 reductase, coupled with an up-regulation of uridine kinase (Table 3, item 1.5). IFN- $\gamma+$ PIC also down-regulated expression of mRNAs encoding receptors for the incretins cholecystokinin-A and gastric inhibitory peptide and of growth hormone receptor (Table 3, item 4.0). This, associated with the observed decrease in insulin and pro-hormone convertase (PC) 1 mRNA levels, and of genes involved in ATP production, could contribute for the decreased insulin se-
Data are expressed as percentage of the total number of modified genes observed in each condition (bold numbers), taken as $100 \%$

cretion observed after treatment of pancreatic islets or beta cells with IFN- $\gamma+$ PIC $[20,45]$.

Several chemokines, cytokines, as well as genes involved in signal transduction, were modified by IFN- $\gamma$ or PIC, alone and specially in combination (Table 3, items 5.0 and 6.0). When tested alone, IFN- $\gamma$ affected expression of the chemokines macrophage inhibitory cytokine-1 (MIC-1) and interferon inducible protein (IP)-10 and of the cytokine IL-15 (Table 3, item 5.0). IL-15, IP-10, MIP-3 $\alpha$, macrophage chemoattractant protein (MCP)-1 and fractalkine mRNAs were induced by PIC and/or the combination of IFN- $\gamma+$ PIC. Induction of RANTES and TNF- $\beta$ mRNAs were also observed in pancreatic beta cells exposed to PIC and/or PIC + IFN- $\gamma$. It has been previously shown that RANTES and IP-10 are secondarily up-regulated by autocrine production of IFN- $\beta$ in RAW 264.7 cells, a murine macrophage cell line [46]. In the present microarray analysis however, neither PIC nor IFN- $\gamma$, nor PIC and IFN- $\gamma$ together, modified the expression of IFN- $\alpha$, IFN- $\beta$ and IL-1 $\beta$, at least at our selected time points (data not shown).

Interestingly, the concomitant presence of PIC and IFN- $\gamma$ led to up-regulation of Notch1 receptor and one of his ligands, Delta-1. Presenilin-2, an enzyme required for intramembraneous proteolysis of Notch was also up-regulated (Table 3; item 6.0). PIC and IFN- $\gamma$, however, did not modify expression of Jagged, another Notch ligand (data not shown). There was also upregulation of JAK-2, Pim-3 serine threonine kinase and CL100 protein tyrosine phosphatase which, asso- 
Table 3. List of selected genes modified after a 6- or 24-hour exposure to PIC and/or IFN- $\gamma$

\begin{tabular}{|c|c|c|c|c|c|c|c|}
\hline \multirow[t]{2}{*}{ Cluster/GAN } & \multirow[t]{2}{*}{ Gene Name } & \multicolumn{3}{|l|}{$6 h$} & \multicolumn{3}{|l|}{$24 \mathrm{~h}$} \\
\hline & & IFN- $\gamma$ & PIC & IFN- $\gamma+\mathrm{PIC}$ & IFN- $\gamma$ & PIC & IFN- $\gamma+\mathrm{PIC}$ \\
\hline
\end{tabular}

\subsection{Metabolism}

\subsection{Carbohydrates}

X59737 Creatine kinase-ubiquitous *

M86240 Fructose-1,6-bisphosphatase

M13979 Glucose transporter type 1 (GLUT 1)

L28126 Glucose transporter type 2 (GLUT 2) *

M54926 Lactate dehydrogenase A

L25387 Phosphofructokinase c (PFK-c)

\subsection{Arginine metabolism and NO formation}

J02720 Arginase

X12459 Argininosuccinate synthetase

AA957917 Cationic amino acid transporter-1

D44591 iNOS*

1.3 Aminoacids (other than arginine)

AA942685 Cysteine dioxygenase

M72422

AI176504

AA852004

Glutamic acid decarboxylase 65 (GAD 65)

M84648

Glutaminase

Glutamine synthetase

L-amino acid decarboxylase

7.9

$5.4 \quad 11.4$

10.9

3.1

$-6.8$

$-2.7$

3.9

1.4 Lipids

AA799489

L27075

M29249

$\mathrm{X} 13722$

AI044900

S81497

M38566

AF036761

S70011

Acyl-CoA oxidase

ATP-cytrate lyase

3-hydroxy-3 methylglutaryl coenzyme A

(HMGcoA) reductase

\section{LDL-receptor}

Long-chain acyl-CoA synthetase

Lysosomal acid lipase

Mitochondrial cytochrome P450 (P450C27)

Stearyl-CoA desaturase 2

Trycarboxilate carrier (mitochondrial)

1.5 ATP production and processing

D00636 Cytochrome b5 reductase (NADH)*

AI169265 NADH dehydrogenase (ubiquinone)

$1 \alpha$ subcomplex 4

AA859827 Uridine kinase

\subsection{Miscellaneous}

AA799406 Cytochrome P450 monooxygenase

D87839

GABA transaminase

U27518

UDP-glucuronosyltransferase

$-18.4 \quad-2.6 \quad-2.5$

\subsection{Protein synthesis, modification, and secretion}

$\begin{array}{ll}\text { AA859966 } & \text { 18S rRNA } \\ \text { AI008852 } & \text { Elongation factor } 1 \alpha \\ \text { AA892250 } & \text { Lysyl-tRNA synthetase } \\ \text { M24353 } & \text { Mannosidase } \alpha \text { type II } \\ \text { AI169327 } & \text { Metalloproteinase inhibitor* } \\ \text { M83676 } & \text { RAB12 } \\ \text { AA893080 } & \text { Selenocysteine lyase } \\ \text { AI007857 } & \text { SNAP-25 interacting protein hrs-2 } \\ \text { AJ006855 } & \text { Synaptojanin } \\ \text { U56261 } & \text { Synaptosomal associated protein }\end{array}$

(SNAP-25a)
$-4.6$

4.3

3.1

10.5

9.1

$-2.8$

$-5.2$

$-11.9$ $\begin{array}{rr} & 3.1 \\ -3.8 & -3.9\end{array}$

3.1

10.2

$-11.4$

$-2.5$

8.1

$-3.2$

3.5

$\begin{array}{rrrrr} & & -4.7 & & -5.0 \\ 3.4 & 5.0 & 2.7 & 3.3 & 5.9\end{array}$

4.3

$\begin{array}{lll}6.9 & 5.8 \quad 12.9\end{array}$
3.0

7.0

2.8

$-5.8$

9.0 
Table 3. (continued)

\begin{tabular}{|c|c|}
\hline Cluster/GAN & Gene Name \\
\hline \multicolumn{2}{|c|}{ 3.0 Ionic channels, ions transporters and related proteins } \\
\hline U69884 & Calcium-activated potassium channel rSK3 (SK) \\
\hline M31178 & Calbindin \\
\hline X90642 & Multidrug resistance protein (ID:1) \\
\hline L35771 & Potassium channel \\
\hline AF048828 & Voltage dependent anion channel (RVDAC 1$)^{*}$ \\
\hline \multicolumn{2}{|c|}{ 4.0 Hormones, growth factors and related genes } \\
\hline X01032 & Cholecystokinin (CCK) precursor \\
\hline E12746 & Cholecystokinin-A receptor* \\
\hline L20913 & Endothelial growth factor form 3 \\
\hline L19660 & Gastric inhibitory peptide receptor \\
\hline S49003 & Growth hormone receptor (short isoform) \\
\hline Z83757 & Growth hormone receptor \\
\hline M25584 & Insulin 1 \\
\hline Y07534 & Mitochondrial vitamin $\mathrm{D}(3)$ 25-hydroxylase \\
\hline M83745 & Prohormone convertase- 1 \\
\hline S40669 & Prohormone convertase 2 \\
\hline M25804 & Rev-ErbA-a * \\
\hline M93273 & Somatostatin receptor type 2 \\
\hline X63574 & Somatostatin receptor type 3 \\
\hline M23643 & Thyrotropin releasing hormone* \\
\hline M32167 & Vascular endothelial growth factor (VEGF)* \\
\hline AF022952 & Vascular endothelial growth factor B \\
\hline \multicolumn{2}{|c|}{ 5.0 Cytokines, chemokines and related receptors } \\
\hline AA799761 & $\mathrm{CD}-40$ \\
\hline D11445 & CINC-1 \\
\hline AF030358 & Fractalkine \\
\hline U68272 & Interferon- $\gamma$ receptor \\
\hline U69272 & Interleukin $15^{*}$ \\
\hline $\mathrm{X} 17053$ & Macrophage chemoattractant protein-1 (MCP-1)* \\
\hline AJ011969 & Macrophage inhibitory cytokine-1 (MIC-1) \\
\hline 53312 & MIP-3 $\alpha$ \\
\hline U17035 & Mob-1/ IP-10 \\
\hline U94330 & Osteoprotegerin \\
\hline AI009658 & RANTES \\
\hline L00981 & TNF- $\beta$ \\
\hline
\end{tabular}

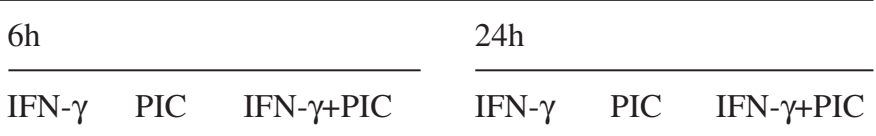

3.0 Ionic channels, ions transporters and related proteins

U69884 Calcium-activated potassium channel rSK3 (SK)

M31178 Calbindin $\quad-3.8$ $-3.8$

L35771

Potassium channel

$-6.4$

\section{4}

58.4

98.9

$-5.8$

$-5.0$

$-3.1$

$-9.7$

\subsection{Cytokine and dsRNA processing and signal transduction}

$\begin{array}{ll}\text { M64780 } & \text { Agrin* } \\ \text { A170268 } & \text { B-2 microgobulin } \\ \text { S74351 } & \text { 3CH134/CL100 protein tyrosin phosphatase } \\ \text { U78889 } & \text { Delta1 } \\ \text { AA924925 } & \text { ER transmembrane protein } \\ \text { M80367 } & \text { Guanylate nucleotide binding protein 2 } \\ \text { AA891944 } & \text { INF- } \gamma \text { induced GTPase } \\ \text { U13396 } & \text { Janus protein tyrosine kinase 2 (JAK-2)* } \\ \text { AA875327 } & \text { Lim-kinase 1 } \\ \text { AF013144 } & \text { MAP-kinase phosphatase (cpg21) } \\ \text { D89863 } & \text { M-Ras* } \\ \text { X57405 } & \text { Notch-1* } \\ \text { D84667 } & \text { Phosphatidylinositol 4-kinase } \\ \text { J03806 } & \text { Phospholipase C } \\ \text { AF086624 } & \text { Pim-3 serine threonine kinase } \\ \text { X99267 } & \text { Presenilin-2 } \\ \text { M18330 } & \text { Protein kinase C delta subspecies } \\ \text { U02553 } & \text { Protein tyrosine phosphatase } \\ \text { AF077000 } & \text { Protein tyrosine phosphatase TD14 (PTP-TD14) }\end{array}$


Table 3. (continued)

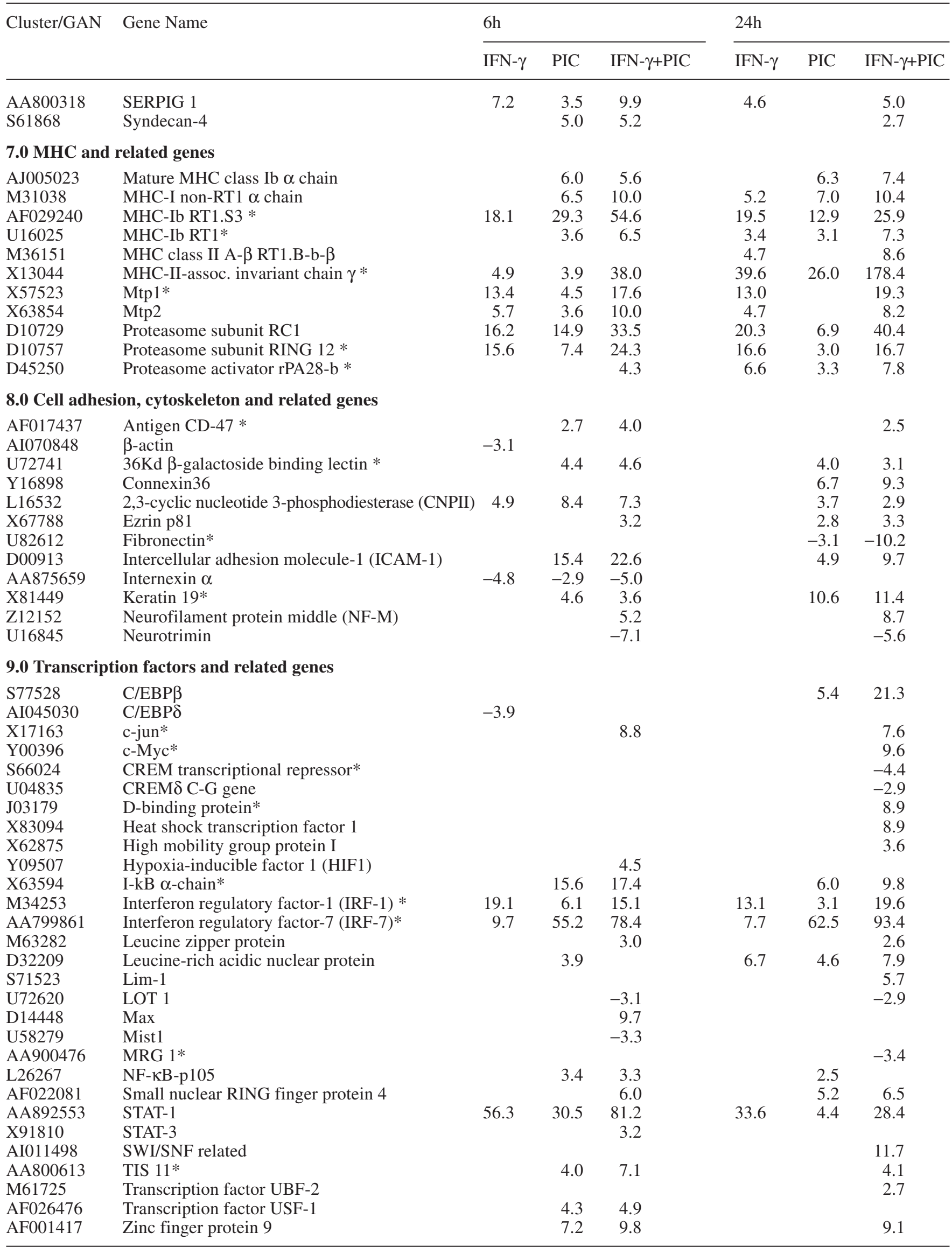


Table 3. (continued)

\begin{tabular}{|c|c|c|c|c|c|c|c|}
\hline \multirow[t]{2}{*}{ Cluster/GAN } & \multirow[t]{2}{*}{ Gene Name } & \multicolumn{3}{|l|}{$6 \mathrm{~h}$} & \multicolumn{3}{|l|}{$24 \mathrm{~h}$} \\
\hline & & IFN- $\gamma$ & PIC & IFN- $\gamma+$ PIC & IFN- $\gamma$ & PIC & IFN- $\gamma+\mathrm{PIC}$ \\
\hline
\end{tabular}

\subsection{RNA synthesis and splicing factors}

AF044910 Survival motor neuron*

11.0 Cell cycle

$\begin{array}{ll}\text { D16308 } & \text { Cyclin D2 } \\ \text { U24174 } & \text { p21/WAF1 } \\ \text { U75404 } & \text { SSeCKs 322 }\end{array}$

U75404 SSeCKs 322

17.2
9

12.0 Defense/repair

AI070295

AF020618

GADD45

D42148

U73174

AI138143

Z27118

AA875620

AI176456

GADD34 (mouse MyD116; rat PEG-3) *

Y00497

X52711

M76704

J02722

AA848563

Gas-6 growth arrest specific

Glutathione reductase

Glutathione S-transferase

Hsp 70 gene $1 / 2$ *

Hsp 70 gene 3

Metallothionein 2

MnSOD

MX1

O-6-methylguanine-DNA methyltransferase (MGMT)

AI138143

Heme oxygenase

Heat shock protein 70-1

Glutathione S-transferase

\subsection{Apoptosis and ER stress response and related genes}

S76511

M31178

Bax

L18889

U77931

AF025671

C07012

U30186

U41853

X62950

M96630

Z14030

\section{Calbindin $\mathrm{d} 28 \mathrm{~K}$}

Calnexin

Calreticulin

Caspase 2

Cyclophilin c

GADD 153 (Growth arrest DNA damage 153)

$150 \mathrm{kDa}$ oxygen regulated protein (ORP150) (pBUS30) with repetitive elements

Sec 61 homolog

TRAP-complex gamma subunit

\subsection{Anti-viral response}

L2928

Double-stranded RNA-dependent protein kinase (PKR)

U18942 Double-stranded RNA-specific adenosine

X52713 Mx3

Z18877 2',5'-oligoadenylate synthetase (OAS)

\subsection{Miscellaneous}

Y07704 Best-5*

D88250 Complement C1

L21711 Galectin-5

M62642 Hemopexin

M81855 P glycoprotein 1

AA875037 Serine protease inhibitor 15 (spi15)

Data are shown as fold-variation corresponding to the gene with the indicated access number. The genes are ordered alphabeticaly in each cluster. The data are means of individual duplicate hybridizations. mRNAs were considered as modified by dsRNA and/or IFN- $\gamma$ when the mean fold change of the duplicates was $\geq 2.5$, and both individual fold change values were

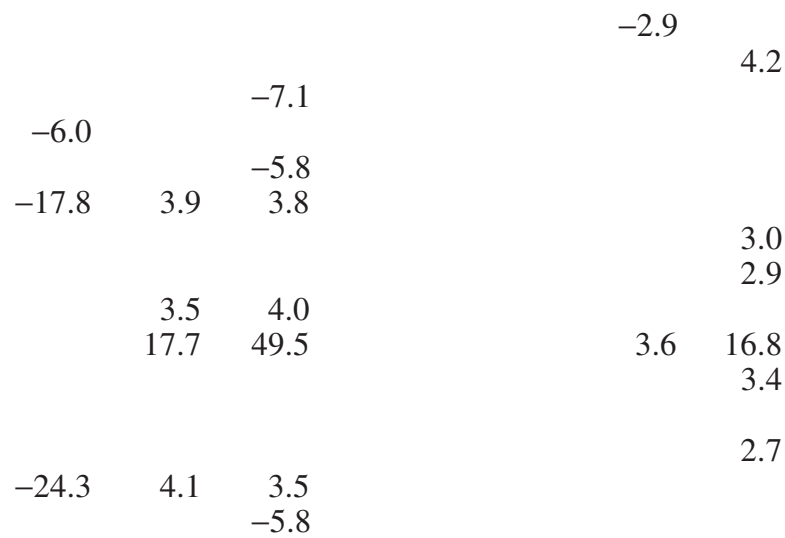

$-3.8$

$-2.9$

$-3.3$

$\begin{array}{rrrrrr} & & & 2.9 & 2.7 & 4.0 \\ & 2.7 & 3.2 & 2.7 & 3.8 & 4.5 \\ -4.4 & & 2.6 & & & 9.0 \\ -14.8 & & & & & -2.8 \\ -14.6 & -3.7 & 5.0 & & & \end{array}$

$\begin{array}{rrrr}8.6 & 9.9 & & \\ 5.8 & 7.2 & 8.2 & 9.3 \\ & & & \\ 43.9 & 36.6 & 4.7 & 19.7 \\ 11.3 & 10.7 & 2.6 & 2.6\end{array}$

24.4

$\begin{array}{rr}60.5 & 60.9 \\ 4.7 & 15.0 \\ 23.8 & 22.8 \\ 9.1 & 8.1 \\ & 11.7\end{array}$

$\begin{array}{rrr}5.2 & 38.6 & 99.4 \\ 7.1 & 7.9 & 22.0 \\ 7.2 & 17.7 & 19.5 \\ & 13.2 & 10.9 \\ & & 8.6 \\ & & 6.4\end{array}$

$\geq 2.0$. Decreased expression compared with respective controls (beta cells not exposed to IFN- $\gamma$ and/or PIC; 6 or $24 \mathrm{~h}$ ) is indicated by "-" preceding the fold-change value; absence of sign means increased expression. * indicates gene detected by more than one probe. GAN, GeneBank Accession Number 
ciated with a decrease in MAP-kinase phosphatase (cpg21) by exposure to PIC alone or in combination with IFN- $\gamma$ (Table 3; item 6.0), could affect beta-cell signal transduction by acting on key phosphorylation/ dephosphorylation steps.

Genes related to antigen presentation were induced to a major extent after both 6 and $24 \mathrm{~h}$ (Table 3, item 7.0). Increased expression of MHC-Ib RT1, MHC-II and proteasome subunit RC1 and RING12 were observed with both IFN- $\gamma$ and PIC alone, but the two agents often showed additive effects. MTP-1 and MTP-2, proteins involved in the "machinery" for MHC class I presentation, were also up-regulated by both agents.

IFN- $\gamma$ and/or PIC led to up- and down-regulation of numerous transcription factors and associated proteins (Table 3, item 9.0). Of note, among the 41 transcription factors modified, $63 \%$ of them were affected only in the presence of both agents, the sole condition leading to beta cell apoptosis. There was up-regulation of c-jun, c-Myc, C/EBP $\beta$, NF-кB, Lim-1 and STAT-1. Up-regulation of these transcription factors was also observed after beta cell exposure to IL- $1 \beta$ and IFN- $\gamma$, another treatment leading to apoptosis. The microarray results also showed up-regulation of other transcription factors not described before in beta cells exposed to cytokines, including heat shock transcription factor 1, hypoxia-inducible factor 1, STAT-3, Max and USF-1 (Table 3; item 9.0). Nuclear Ring Finger protein 4 (RNF4) and SWI/SNF, mRNAs encoding for multiprotein complexes remodelling chromatin, which are required for positive and negative control of various cellular pathways, were also up-regulated following beta-cell exposure to PIC and IFN- $\gamma$ (Table 3; item 9.0).

IFN- $\gamma$ alone induced an early ( $6 \mathrm{~h})$ decrease in two mRNAs potentially involved in beta-cell defence/repair, namely glutathione reductase and hsp70 (Table 3; item 12.0), and of two endoplasmic reticulum (ER) chaperones that could contribute to defence against ER stress, i.e. calnexin and calreticulin (Table 3; item 13.0). In contrast, PIC, especially in combination with IFN- $\gamma$, up-regulated several defence/repair genes after both 6 and $24 \mathrm{~h}$. Among them, IFN- $\gamma+$ PIC modified expression of MnSOD, haeme oxygenase, hsp 70, PEG-3/MyD116 (the rat and mouse homologs of human GADD34) and the DNA repair enzyme O-6methylguanine-DNA methyltransferase (Table 3; item 12.0).

Among genes related to apoptosis, we observed induction of several putative pro-apoptotic genes by PIC alone or combined to IFN- $\gamma$. These included Bax, caspase 2, the cyclin-dependent kinase inhibitor p21/WAF1 and GADD153/CHOP, an ER stressresponse transcription factor (Table 3, items 11 and 13.0). Of interest, Bip/GRP78 and bcl-2 expression were unaffected by IFN- $\gamma$ and/or PIC, at least at our selected time points (see below).

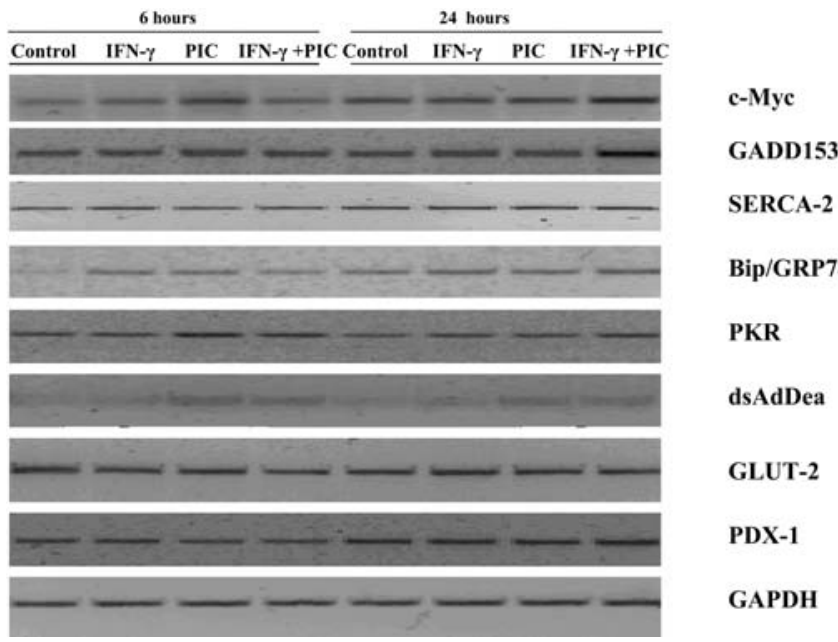

Fig. 2. RT-PCR analysis of PKR, dsRNA-specific adenosine deaminase, c-Myc, GADD153/CHOP, SERCA-2, GLUT-2, PDX-1, Bip/GRP78 and GAPDH mRNA expression by beta cells exposed for 6 to $24 \mathrm{~h}$ to: IFN- $\gamma(1000 \mathrm{U} / \mathrm{ml})$, PIC $(100 \mu \mathrm{g} / \mathrm{ml})$ or IFN- $\gamma+$ PIC. The cDNA samples were amplified in parallel with GAPDH-specific primers, confirming similar loading in all lanes. The figure is representative of four similar experiments

Treatment of beta cells for 6 or $24 \mathrm{~h}$ with PIC alone induced expression of genes promoting resistance to viral infection, such as dsRNA-activated protein kinase (PKR, also named eIF- $2 \alpha$ kinase), $2^{\prime}, 5^{\prime}$-oligoadenylate synthetase (OAS) and RNA-specific adenosine deaminase (ADAR) (Table 3; item 14.0); addition of IFN- $\gamma$ neither modified the pattern of expression nor the magnitude of this response. Moreover, IFN- $\gamma$ alone did not induce any of these genes.

Confirmation by RT-PCR and real-time RT-PCR of genes identified as modified by IFN- $\gamma$ and/or PIC. Eight genes of special interest were selected for confirmation by RT-PCR. Six of the selected genes were detected as "changed" in at least one of our experimental conditions in the array analysis. Thus, ADAR and PKR, both involved in anti-viral response; the oncogene c-Myc; GADD153, an ER stress-induced transcription factor; and the transcription factor $\mathrm{CEBP} / \beta$ were scored as increased; in contrast, expression of GLUT-2, the beta-cell specific glucose transporter, was detected as decreased by $24 \mathrm{~h}$ exposure to the combination of PIC + IFN- $\gamma$. The RT-PCR results confirmed the data obtained in the microarray for five of the six genes under consideration (Fig. 2). The altered expression of $\mathrm{CEBP} / \beta$, however, could not be confirmed (data not shown). The up-regulation of GADD153 mRNA observed after 24-h exposure to IFN- $\gamma$ and PIC (nine-fold increase, as observed by microarray analysis) was also confirmed by real-time RT-PCR, the ratio of GADD153/GAPDH mRNAs reaching 9.1 \pm 1.7 -fold increase compared with controls $(n=3, p<0.05)$. Bip/GRP78, a resident ER chaper- 


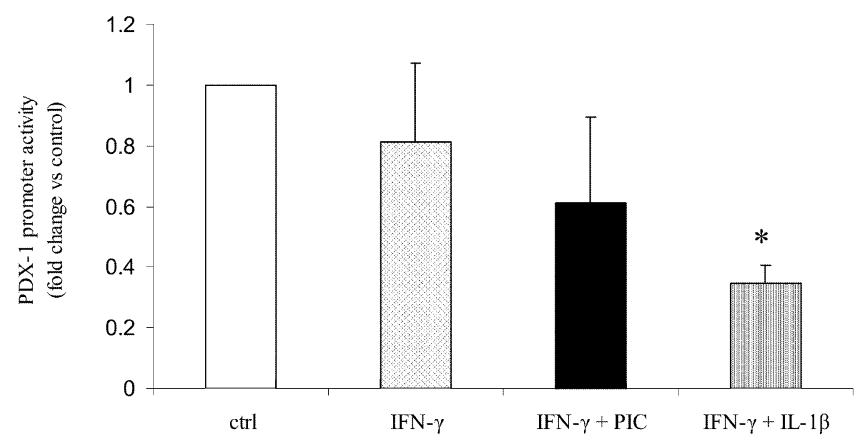

Fig. 3. Effect of IFN- $\gamma$, PIC, IFN- $\gamma+$ PIC and IL- $1 \beta+$ IFN- $\gamma$ on $p d x-1$ promoter activity. After transfection with the $p d x-1$ and pRL-CMV plasmid constructs, purified beta cells were treated for $24 \mathrm{~h}$ with IFN- $\gamma(1000 \mathrm{U} / \mathrm{ml})$, PIC $(100 \mu \mathrm{g} / \mathrm{ml})$ and/or IL-1 $\beta(50 \mathrm{U} / \mathrm{ml})$. Luciferase activities of PDX-1 plasmid were corrected for those obtained with the pRL-CMV plasmid in the same sample. Data are expressed relative to the value obtained in the control condition, taken as 1.0. Results are means \pm SEM of four to five experiments. $* p<0.0005$ vs. control; Student's paired $t$ test

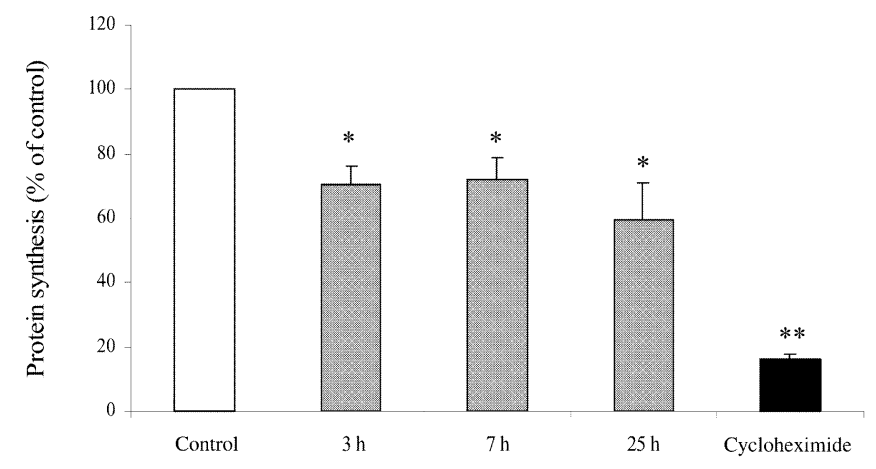

Fig. 4. Effect of IFN- $\gamma$ and PIC on beta-cell total protein biosynthesis. Beta cells were cultured for $23 \mathrm{~h}$ in the absence (control) (white column) or presence for 1,3 and $23 \mathrm{~h}$ of IFN- $\gamma$ $(1000 \mathrm{U} / \mathrm{ml})+$ PIC $(100 \mu \mathrm{g} / \mathrm{ml})($ grey columns $)$. A further $2-\mathrm{h}$ incubation was then carried out under the same experimental conditions but in the additional presence of $\mathrm{L}-\left[4,5-{ }^{3} \mathrm{H}\right]$ leucine $(370 \mathrm{kBq} / \mathrm{ml})$. As positive control, control cells pre-cultured for $23 \mathrm{~h}$ were exposed to cycloheximide $(10 \mu \mathrm{mol} / \mathrm{l})$ during the final 2-h incubation period (black column). The results were calculated as percentage of the tritiated leucine incorporated into control cells, taken as $100 \%$. Data are means \pm SEM of six separate experiments. * $p<0.05, * * p<0.001$ vs. control; Student's paired $t$ test

could lead to a decrease in protein synthesis initiation, we evaluated total protein biosynthesis in beta cells cultured for 3,7 or $25 \mathrm{~h}$ in the presence or absence (control) of PIC and IFN- $\gamma$. As positive controls, the incorporation of tritiated leucine was carried out in the presence of cycloheximide, a well known inhibitor of protein synthesis. Exposure of beta cells to PIC and IFN- $\gamma$ induced a mild decrease in protein synthesis at each time point (Fig. 4), in the range of 30-40\% $(p<0.05$, paired Student's $t$ test), while cycloheximide reduced protein biosynthesis by more than $80 \%$ $(p<0.0005$, paired Student's $t$ test $)$.

\section{Discussion}

The present study is the first attempt to comprehensively define the repertoire of dsRNA- and IFN- $\gamma$-induced genes in primary pancreatic beta cells. Using microarray analysis, 3759 genes were detected as expressed in beta cells. Of these, 348 (nearly $10 \%$ of the total) were found as changed by dsRNA and IFN- $\gamma$, alone or in combination, after 6- or 24-h exposure. The large number of genes modified by dsRNA and IFN- $\gamma$, encoding for proteins involved in a broad range of beta-cell functions, emphasises the complex nature of beta-cell responses to two putative mediators of early insulitis. From the genes detected as changed, $38 \%$ were either induced by IFN- $\gamma$ or by dsRNA, while 58\% showed an additive or a potentiating effect by the combination of both agents; only $4 \%$ of the modified genes were similarly increased/decreased by dsRNA and IFN- $\gamma$, without an additive effect by both

As mentioned above, some genes related to ER stress were modified by PIC + IFN- $\gamma$. Since ER stress 


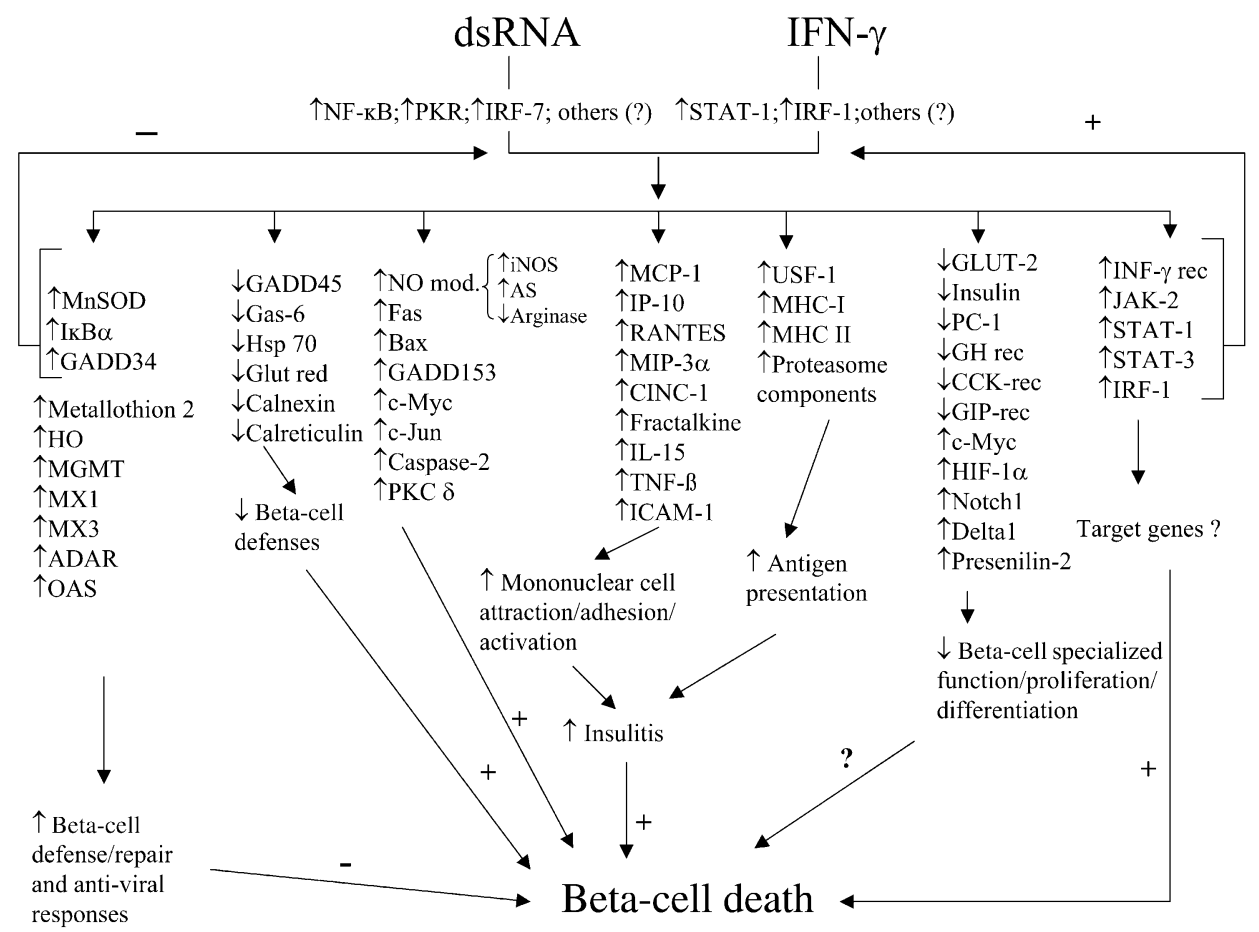

Fig. 5. Proposed model for PIC and/or IFN- $\gamma$ effects on pancreatic beta cells. Explanations about the figure are provided within the text. Metallothion 2 metallothionein 2; HO haeme oxygenase; MGMT O-6-methylguanine-DNA methyltransferase; $A D A R$ RNA-specific adenosine deaminase; $O A S 2^{\prime}, 5^{\prime}$-oligoadenylate synthetase; glut red glutathione reductase; $N O$ mod. NO module; $A S$ argininosuccinate synthetase; $G H$ rec growth hormone receptor; $C C K$ rec cholecystokinin receptor; GIP rec gastric inhibitory peptide receptor; IFN- $\gamma$ rec IFN- $\gamma$ receptor

agents. This, and the fact that dsRNA mostly increases mRNA expression at $6 \mathrm{~h}(94 \%$ of the genes defined as increased), while IFN- $\gamma$ has mainly an inhibitory effect at this time point ( $72 \%$ of the genes defined as decreased), suggests that dsRNA and IFN- $\gamma$ signal via different and complementary pathways. Comparison of the present data with our previous microarray analysis of beta cells exposed to IL- $1 \beta$, alone or in combination with IFN- $\gamma[24,25]$, indicates a nearly $50 \%$ difference in the pattern of gene expression, suggesting that dsRNA has also important points of differences in signalling as compared to IL-1 $\beta$. Of note, and in agreement with our previous observations [22], neither dsRNA nor IFN- $\gamma$, nor a combination of both agents, changed beta-cell expression of IL- $1 \beta$ or IL$1 \alpha$ in the microarray analysis. As previously shown $[21,22]$, and confirmed in the present study, beta cells exposed for 3-6 days to dsRNA + IFN- $\gamma$, but not to either agent alone, undergo cell death by apoptosis. These beta cells also present initial adaptive responses that are part of the early host reaction to a viral infection and contribute to amplify immune recognition and immune response against the infective agent [22]. How can we integrate these functional responses with the complex pattern of dsRNA and/or IFN- $\gamma$-induced gene expression observed in our microarray analysis? A general model, based on the present data, is proposed in Fig. 5 and discussed below. Due to space limitations, not all genes shown in Fig. 5 and Table 3 are discussed here; additional information on these genes is presented in our previous publications dealing with microarray analysis of pancreatic beta cells $[24,25,26,37]$.

Activation of PKR and of the transcription factor $\mathrm{NF}-\kappa \mathrm{B}$ are important mediators of dsRNA signal transduction in other cell types [13, 49, 50], and these pathways have been shown to transduce at least part of the effects of dsRNA, including apoptosis, in beta cells $[21,22,45,50]$. We observed both an induction of the NF- $\mathrm{KB}$ precursor p105 and of several well defined beta-cell NF- $\kappa \mathrm{B}$-dependent genes, such as iNOS [51], MCP-1 [41] and MnSOD [52]; there was also a nearly 10-fold increase in PKR mRNA expression. Another gene induced to a major extent (more than 50 -fold) by dsRNA, in an effect potentiated by IFN- $\gamma$, is the transcription factor interferon regulatory factor (IRF)-7. IRF-7 is induced by dsRNA and/or interferons (mostly IFN- $\alpha$ and IFN- $\beta$ ) in other cell types, an effect mediated by the transcription factors NF- $\kappa B$ and STAT-1 [53, 54]. dsRNA increased STAT-1 expression by more than 50 -fold, an effect potentiated by IFN- $\gamma$ at $6 \mathrm{~h}$ (present data). IRF-7 and IRF-3 (not found as modified in the array; data not shown) play critical roles in the innate response to a viral infection [53] and IRF-7 also contributes to IFN- $\gamma$-mediated apoptosis [55]. Among the downstream genes regulated by IRF-7, in cooperation with NF- $\kappa B$, is the CC chemokine RANTES [56]. We observed that PIC increased RANTES expression by more than 100-fold. 
The agreement between the effects of dsRNA on the expression of genes upstream (STAT-1) and downstream (RANTES) of IRF-7 suggests that this transcription factor participates in the signal transduction of dsRNA in beta cells. Another pathway of dsRNA signalling is via activation of the toll-like receptor 3 (TLR3) [57], but it is unknown whether this receptor is expressed and functional in beta cells.

Signal transduction by IFN- $\gamma$ is mediated via binding of the cytokine to the IFN- $\gamma$ receptor. This is followed by autophosphorylation and activation of the Janus tyrosine kinases 1 and 2 (JAK-1/2), which then phosphorylate and activate STAT-1. Activated STAT-1 migrates to the nucleus, where it regulates the expression of several genes, including the transcription factor IRF-1, contributing to both changes in beta-cell function and the induction of apoptosis [10]. Beta-cell exposure to dsRNA and IFN- $\gamma$ up-regulates nearly all these key steps for IFN- $\gamma$ signal transduction (Fig. 5). This, and the lack of detectable effects of dsRNA and/or IFN- $\gamma$ on the expression of IFN- $\alpha$ and IFN- $\beta$ (probes for both cytokines were present in the array), at least at the time points studied, indicates that IFN- $\gamma$ might have a major role in the early responses of beta cells to a viral challenge.

While the observations described above suggest a positive feedback on IFN- $\gamma$ signal transduction, there seems to be a negative feedback operating for dsRNA signalling. Activation of the transcription factor NF$\kappa \mathrm{B}$ has a pro-apoptotic role in beta cells exposed either to IL-1 $\beta+$ IFN- $\gamma[58,59]$ or to dsRNA + IFN- $\gamma$ [22]. MnSOD and IKB $\alpha$ are two genes that might participate in beta-cell defence against apoptosis by decreasing NF- $\kappa B$ activation $[60,61]$, and both mRNAs were induced by dsRNA. MnSOD is a NF- $\mathrm{BB}$ dependent [52] mitochondrial antioxidant enzyme, and overexpression of MnSOD protects beta cells against immune-mediated damage [62]. NF- $\kappa \mathrm{B}$ also regulates I $\kappa \alpha \alpha$, and increased I $\mathrm{B} \alpha$ concentration both prevents $N F-\kappa B$ migration to the nucleus and removes $\mathrm{NF}-\kappa \mathrm{B}$ already present in the nucleus [63].

As discussed above, another effect of dsRNA is to up-regulate PKR [64]. Once activated, PKR phosphorylates, among other substrates, the small subunit of the eukaryotic initiation factor $2 \alpha$ (eIF $2 \alpha$ ), reducing translation initiation and severely decreasing total cellular protein synthesis. This effect hampers viral replication but, if prolonged, could trigger apoptosis [65]. We observed, however, that beta cells exposed for different time points to dsRNA and IFN- $\gamma$ have only a $30-40 \%$ inhibition of total protein biosynthesis. These apparently divergent findings can be explained by the observation that GADD34 (human homolog of mouse Myd116 or rat progression elevated gene-3), a stressinducible phosphatase, dephosphorylates eIF $2 \alpha$ and induces partial translational recovery after $2-8 \mathrm{~h}$ of cellular stress [66]. We presently observed that GADD34 mRNA is up-regulated by dsRNA + IFN- $\gamma$, suggesting that this phosphatase provides an additional negative feedback on dsRNA effects.

Despite the up-regulation of $\mathrm{I} \kappa \mathrm{B} \alpha, \mathrm{MnSOD}$, GADD34 and other putative defence/repair genes (Fig. 5), prolonged exposure of beta cells to dsRNA and IFN- $\gamma$ eventually culminates in apoptosis. This could be at least in part due to inhibition of several important "defence/repair" genes, and induction of genes that directly contribute to beta-cell death (Table 3; Fig. 5). Decreased expression of "defence" genes [24] seems to be mostly an early effect of IFN- $\gamma$. Two of these genes, calnexin and calreticulin, are chaperones located in the endoplasmic reticulum (ER) [67], and their early inhibition by IFN- $\gamma$ could render the beta cells more susceptible to ER stress induced by the subsequent (after $6 \mathrm{~h}$ ) production of nitric oxide [24, 25, 67, 68]. GADD153, a transcription factor involved in the execution of ER-mediated apoptosis [67], is up-regulated by dsRNA + IFN- $\gamma$ at $24 \mathrm{~h}$. IL- $1 \beta+$ IFN- $\gamma$ also induce GADD153 up-regulation in beta cells $[24,25]$, an effect mediated by NF- $\kappa B$ activation and consequent increase in iNOS expression and nitric oxide formation [25]. Of note, blocking iNOS activity prevents IL- $1 \beta+$ IFN- $\gamma$-induced GADD 153 expression $[25,26]$, but does not prevent apoptosis in human or rodent beta cells $[34,36]$ or in insulinproducing cells [26]. Similarly, the use of iNOS blockers decreased dsRNA + IFN- $\gamma$-induced beta-cell necrosis, but not apoptosis [21, 22]. Thus, it seems that cytokines or dsRNA + IFN- $\gamma$ lead to ER stress in beta cells via NO production, but ER stress is not the main mechanism leading to beta cell apoptosis.

Probes for several members of the bcl-2 family of pro- and anti-apoptotic genes [69], and for different caspases [70], were present in the array, including bcl-2, bcl-xL, Bak, Bax, Bid, Bad, caspase 1 (ICE), caspase 2, caspase 6 and caspase 7. Of these, only Bax and caspase 2 were found to be modified, both maximally induced by dsRNA and IFN- $\gamma$ at $24 \mathrm{~h}$. The proapoptotic Bax homodimerizes through its $\mathrm{BH} 3$ domain, and forms heterodimers with bcl-2 and other proteins. An increased ratio between Bax and bcl-2 contributes to the mitochondrial release of cytochrome $\mathrm{c}$, and other pro-apoptotic proteins, triggering the "execution" phase of apoptosis [71]. dsRNA and IFN- $\gamma$ increase Bax expression without modifying bcl-2, which could tilt the balance in favour of cell death. Up-regulation of c-Myc was observed under the same experimental conditions and at the same time point as Bax, and it is conceivable that, as described for other cell types [72], the pathways mediated by both proteins synergize to induce cell death. Caspase 2 is an upstream caspase, contributing to apoptosis by activating executioner caspases, such as caspases 3 and 7 [70]. Caspase-2 activity is also required for translocation of Bax to the mitochondria and the consequent release of cytochrome c [73]. Finally, dsRNA-induced Fas expression might render the beta cells more sus- 
ceptible to death induced by FasL-expressing mononuclear cells [22].

Beta cells exposed to dsRNA and IFN- $\gamma$ have a functional inhibition that precedes cell death [20, 21, 22]. This might be due to excessive production of NO and consequent impairment in glucose oxidation, but other potentially contributory elements were observed in our microarray analysis. Thus, there was a decrease in the glucose transporter GLUT-2, of both insulin and PC-1, an enzyme involved in the conversion of proinsulin to insulin, and in the receptors for the incretins GIP and CCK. We have previously observed that IL$1 \beta+$ IFN- $\gamma$ decrease the expression of several genes related to differentiated beta-cell functions and preservation of beta-cell mass [24, 25]; and inhibition of these genes was associated to a $50 \%$ decrease in the expression of $p d x-1$. PDX-1 has a crucial role in maintaining the differentiated phenotype of beta cells [24, $25,74]$. In contrast, dsRNA + IFN- $\gamma$ decrease insulin mRNA expression and release, without affecting neither $p d x-1$ mRNA expression nor activity of the $p d x-1$ promoter (present data). If $p d x-1$ is not involved in this process of loss of beta-cell differentiated functions, which other genes could participate in it? c-Myc was detected as up-regulated in the array, and increased expression of this oncogene suppresses insulin gene transcription by inhibiting NeuroD/BETA2 [75]. Another intriguing finding was the up-regulation of Notch1, delta-1 (both induced by dsRNA + IFN- $\gamma$ at $6 \mathrm{~h}$ ), and of presenilin-2 (induced by dsRNA and IFN- $\gamma$ at 24 h). Delta- 1 is a ligand of the Notch receptor, while presenilins- 1 and 2 are enzymes responsible for the intramembraneous proteolysis and activation of Notch [74, 76, 77, 78]. Differentiation is inhibited in endocrine precursor cells expressing activated Notch receptors, whereas the signalling cells (expressing delta-1) are free to differentiate into endocrine cells [74]. It is thus conceivable that dsRNA and IFN$\gamma$-induced re-expression of genes of the Notch signalling pathway contributes to both the loss of the differentiated beta-cell phenotype, and, together with the observed inhibition of $\mathrm{GH}$ receptor, prevents in a paracrine fashion the growth/differentiation of newly generated beta cells.

The first line of cellular defence against a viral infection is provided by the local innate immunity, which is followed by the adaptive immune response. Both processes are, at least to some extent, integrated $[79,80]$. We have detected induction of several genes that might impair intracellular viral proliferation, including PKR, MX3, double-stranded RNA-specific adenosine deaminase (ADAR) and 2',5'-oligoadenylate synthetase (OAS). These mRNAs were up-regulated by dsRNA at both 6 and $24 \mathrm{~h}$, with little or no additive effect by IFN- $\gamma$. MXs are large GTPases which interfere with viral replication and spread [81], while ADAR hyperedits dsRNAs by converting adenosine to inosine, targeting the dsRNAs for cleavage and re- moval from the cytosol [82]. OAS activates RNAseL, which both decreases total protein synthesis and accelerates the degradation of RNA, affecting viral replication but also contributing to cell dysfunction and eventually apoptosis [83]. To mount the "second line" of defence, namely the adaptive immune response, the infected cells must present the viral antigens bound to HLA molecules and attract immune competent cells to the site of infection. As can be seen from Fig. 5, beta cells exposed to dsRNA and/or IFN- $\gamma$ express several genes related to antigen processing and presentation in the context of MHC class I molecules, and also upregulate several chemokines, adhesion molecules and cytokines that contribute to homing and activation of macrophages, dendritic cells and T-cells. We and others have described before, by differential display and microarray analysis, induction of several of these chemokines, cytokines and MHC-related molecules by IL- $1 \beta$ and IFN- $\gamma[24,25,84]$, and also confirmed their expression at the mRNA and protein level in both rodent and human islets, and in islets isolated from prediabetic NOD mice [68, 84, 85]. Moreover, by use of RT-PCR and 'gene-by-gene' analysis we showed that beta cells exposed to dsRNA and IFN- $\gamma$ express IP-10, MCP-1, MIP-3 $\alpha$ and fractalkine [22], findings confirmed in the present microarray analysis. One chemokine, however, was not described before in beta cells, namely RANTES. The C-C chemokine RANTES (CCL5) attracts monocytes, activated T-cells and immature dendritic cells during inflammation and immune responses, suggesting a role for RANTES in virus-related diseases [86]. Of special interest, RANTES expression in microglia correlates with the initial symptoms of experimental autoimmune encephalomyelitis $[87,88]$ and the chemokine, together with IP-10, MCP-3 and MCP-5, contributes to the distinct Th1 islet inflammatory infiltrate leading to beta-cell destruction in NOD.scid mice infused with islet-specific TCR transgenic CD4 cells [89].

Most information available on the broad molecular effects of dsRNA have been obtained in tumoural cell lines [90], and little is known about the effects of dsRNA or actual viral infection on gene regulation by non- or poorly-dividing cells, such as beta cells. It is conceivable that some of the mechanisms that allow one cell type to eradicate a viral infection in a noncytopathic and cytokine-dependent way might cause death in another cell type [79]. This possibility is of special relevance for Type 1 diabetes, where both viruses and their product, dsRNA, together with locally produced cytokines, such as IFN- $\gamma$ and IL- $1 \beta$, probably play an important role in the initiation and progression of insulitis. Why and how the cellular attempts to eradicate/neutralise the invading virus go wrong in some individuals, giving rise to progressive inflammation and beta-cell death, remain to be determined. Our study, by showing large scale evaluation of mRNAs modified by dsRNA and IFN- $\gamma$ in beta 
cells, provides valuable information to answer this question, and allowed us to propose a comprehensive hypothesis for the molecular regulation of the different cellular responses involved (Fig. 5). The present "data driven" hypothesis needs now to be tested by both targeted "hypothesis driven" experiments and by new microarray and proteomic analysis of rodent and human islet cells exposed either to dsRNA, in the presence of blockers of key signalling pathways, or infected with viruses with a putative pathogenic role in human Type 1 diabetes.

Acknowledgements. This work was supported by grants from the Juvenile Diabetes Foundation International (JDRF) and the Fonds National de la Recherche Scientifique (FNRS), Belgium. We thank the personnel from the Laboratory of Experimental Medicine, ULB, MA. Neef, J. Schoonheydt, M. Urbain and G. Vandenbroeck for technical assistance and C. Demesmaeker for secretarial help. We thank also R. Leeman and the personnel involved in beta-cell purification at the Diabetes Research Center, Vrije Universiteit Brussel, for help in the initial part of the study. This work has been conducted in collaboration with and supported by the JDRF Center for Prevention of Beta-cell Destruction in Europe under grant number 4-2002457.

\section{References}

1. Tisch R, McDevitt H (1996) Insulin-dependent diabetes mellitus. Cell 85:291-297

2. Yoon JW (1997) Pathogenesis of IDDM: environmental factors. In: Pickup J, Williams G (eds) Textbook of diabetes. Blackwell, London, pp 14.1-14.14

3. Todd JA, Bain SC (1992) A practical approach to identification of susceptibility genes for IDDM. Diabetes 41: 1029-1034

4. Onengut-Gumuscu S, Concannon, P (2002) Mapping genes for autoimmunity in humans: type 1 diabetes as a model. Immunol Rev 190:182-194

5. Yoon JW, Kim, AM, Jun HS (1999) Role of viruses in insulin-dependent diabetes mellitus. In: Turtle JR (ed.) Diabetes in the New Millenium. Endocrinology and diabetes. Research Foundation of the University of Sydney, Sydney, Australia, pp 105-117

6. Hyöty H, Taylor KW (2002) The role of viruses in human diabetes. Diabetologia 45:1353-1361

7. Jun HS, Yoon JW (2001) The role of viruses in type 1 diabetes: two distinct cellular and molecular pathogenic mechanisms of virus-induced diabetes in animals. Diabetologia 44:271-285

8. Jenson AB, Rosenberg HS, Notkins AL (1980) Pancreatic islet-cell damage in children with fatal viral infections. Lancet 2:354-358

9. Horwitz MS, Bradley LM, Harbertson J, Krahl T, Lee J, Sarvetnick N (1998) Diabetes induced by Coxsackie virus: initiation by bystander damage and not molecular mimicry. Nat Med 4:781-785

10. Eizirik DL, Mandrup-Poulsen T (2001) A choice of death - the signal-transduction of immune-mediated beta cell apoptosis. Diabetologia 44:2115-2133

11. Vreugdenhil GR, Geluk A, Ottenhoff TH, Melchers WJ, Roep BO, Galama JM (1998) Molecular mimicry in diabetes mellitus: the homologous domain in coxsackie B virus protein 2C and islet autoantigen GAD65 is highly conserved in the coxsackie B-like enteroviruses and binds to the diabetes associated HLA-DR3 molecule. Diabetologia 41:40-46

12. Haverkos HW (1997) Could the aetiology of IDDM be multifactorial? Diabetologia 40:1235-1240

13. Jacobs BL, Langland JO (1996) When two strands are better than one: the mediators and modulators of the cellular responses to double-stranded RNA. Virology 219:339-349

14. Williams BRG (1999) PKR: a sentinel kinase for cellular stress. Oncogene 18:6112-6120

15. Sobel DO, Ewel CH, Zeligs B, Abbassi V, Rossio J, Bellanti JA (1994) Poly I:C induction of alpha-interferon in the diabetes-prone $\mathrm{BB}$ and normal Wistar rats. Doseresponse relationships. Diabetes 43:518-522

16. Der SD, Yang YL, Weissmann C, Williams BRG (1997) A double-stranded RNA-activated protein kinase-dependent pathway mediating stress-induced apoptosis. Proc Natl Acad Sci USA 94:3279-3283

17. Ewel CH, Sobel DO, Zeligs BJ, Bellanti JA (1992) Poly $\mathrm{I}: \mathrm{C}$ accelerates development of diabetes mellitus in diabetes-prone BB rat. Diabetes 41:1016-1021

18. Sobel DO, Newsome J, Ewel CH et al. (1992) Poly I:C induces development of diabetes mellitus in BB rat. Diabetes 41:515-520

19. Rhodes CJ, Taylor KW (1985) Effect of interferon and double-stranded RNA on $\beta$-cell function in mouse islets of Langerhans. Biochem J 228:87-94

20. Heitmeier MR, Scarim AL, Corbett JA (1999) Doublestranded RNA inhibits beta cell function and induces islet damage by stimulating beta cell production of nitric oxide. J Biol Chem 274:12531-12536

21. Liu D, Darville M, Eizirik DL (2001) Double-stranded ribonucleic acid (RNA) induces $\beta$-cell Fas messenger RNA expression and increases cytokine-induced $\beta$-cell apoptosis. Endocrinology 142:2593-2599

22. Liu D, Cardozo AK, Darville MI, Eizirik DL (2002) Double-stranded RNA cooperates with interferon- $\gamma$ and IL-1 $\beta$ to induce both chemokine expression and nuclear factor- $\kappa$ B-dependent apoptosis in pancreatic beta cells: potential mechanisms for viral-induced insulitis and beta cell death in type 1 diabetes mellitus. Endocrinology 143:1225-1234

23. Stears RL, Martinsky T, Schena M (2003) Trends in microarray analysis. Nature Med 9:140-145

24. Cardozo AK, Kruhoffer M, Leeman R, Orntoft T, Eizirik DL (2001) Identification of novel cytokine-induced genes in pancreatic beta cells by high-density oligonucleotide arrays. Diabetes 50:909-920

25. Cardozo AK, Heimberg H, Heremans Y et al. (2001) A comprehensive analysis of cytokine-induced and nuclear factor-kappa B-dependent genes in primary rat pancreatic beta cells. J Biol Chem 276:48879-48886

26. Kutlu B, Cardozo AK, Darville MI, Kruhoffer M, Magnussin N, Orntoft T, Eizirik DL (2003) Discovery of gene networks regulating cytokine-induced dysfunction and apoptosis in insulin-producing INS-1 cells. Diabetes 52:27012719

27. Pipeleers DG, In't Veld PA, Van de Winkel M, Maes E, Schuit FC, Gepts W (1985) A new in vitro model for the study of pancreatic A and B cells. Endocrinology 117:806816

28. Ling Z, Hannaert JC, Pipeleers D (1994) Effects of nutrients, hormones and serum on survival of rat islet $\beta$-cells in culture. Diabetologia 37:15-21

29. Ling Z, Chen M-C, Smismans A et al. (1998) Intercellular differences in interleukin-1 $\beta$-induced suppression of insulin synthesis and stimulation of noninsulin protein synthe- 
sis by rat pancreatic $\beta$-cells. Endocrinology 139:15401545

30. Green LC, Wagner DA, Goglowski J, Skipper PL, Wishnok JS, Tannenbaum SR (1982) Analysis of nitrate, nitrite, and $\left[{ }^{15} \mathrm{~N}\right]$ nitrate in biological fluids. Anal Biochem 126:131138

31. Eizirik DL (1991) Interleukin-1 $\beta$ induces an early decrease in insulin release, (pro)insulin biosynthesis and insulin mRNA in mouse pancreatic islets by a mechanism dependent on gene transcription and protein synthesis. Autoimmunity $10: 107-113$

32. Hoorens A, Van de Casteele M, Kloppel G, Pipeleers D (1996) Glucose promotes survival of rat pancreatic $\beta$-cells by activating synthesis of proteins which suppress a constitutive apoptotic program. J Clin Invest 98:1568-1574

33. Ling Z, Van de Casteele M, Eizirik DL, Pipeleers DG (2000) Interleukin-1 $\beta$-induced alteration in a $\beta$-cell phenotype can reduce cellular sensitivity to conditions that cause necrosis but not to cytokine-induced apoptosis. Diabetes 49:340-345

34. Liu D, Pavlovic D, Chen MC, Flodström M, Sandler S, Eizirik DL (2000) Cytokines induce apoptosis in $\beta$-cells isolated from mice lacking the inducible isoform of nitric oxide synthase (iNOS ${ }^{--}$). Diabetes 49:1116-1122

35. Pavlovic D, Chen M-C, Gysemans CA, Mathieu C, Eizirik DL (1999) The role of interferon regulatory factor-1 in cytokine-induced mRNA expression and cell death in murine pancreatic $\beta$-cells. Eur Cytokine Netw 10:403-411

36. Delaney CA, Pavlovic D, Hoorens A, Pipeleers DG, Eizirik DL (1997) Cytokines induce deoxyribonucleic acid strand breaks and apoptosis in human pancreatic islet cells. Endocrinology 138:2610-2614

37. Eizirik DL, Kutlu B, Rasschaert J, Darville M, Cardozo AK (2003) Use of microarray analysis to unveil transcription factor and gene networks contributing to $\beta$-cell dysfunction and apoptosis. Proc NY Acad Sci (in press)

38. Lee Y, Sultana R, Pertea G et al. (2002) Cross-referencing eukaryotic genomes: TIGR Orthologous Gene Alignments (TOGA). Genome Res 12:493-502

39. Varadi A, Molnar E, Ostenson C-G, Ashcroft SJH (1996) Isoforms of endoplasmic reticulum $\mathrm{Ca}(2+)$-ATPase are differentially expressed in normal and diabetic islets of Langerhans. Biochem J 319:521-527

40. Eizirik DL, Björklund A, Cagliero E (1993) Genotoxic agents increase expression of growth arrest and DNA damage inducible genes GADD 153 and GADD 45 in rat pancreatic islets. Diabetes 42:738-745

41. Kutlu B, Darville M, Cardozo AK, Eizirik DL (2003) Molecular regulation of monocyte chemoattractant protein-1 expression in pancreatic $\beta$-cells. Diabetes 52:348-355

42. Overbergh L, Valckx D, Waer M, Mathieu C (1999) Quantification of murine cytokine mRNAs using real time quantitative reverse transcriptase PCR. Cytokine 11:305-312

43. Giulietti A, Overbergh L, Valckx D, Decallonne B, Bouillon R, Mathieu C (2001) An overview of real-time quantitative PCR: applications to quantify cytokine gene expression. Methods 25:386-401

44. Ben-Shushan E, Marshak S, Shoshkes M, Cerasi E, Melloul DA (2001) Pancreatic beta-cell-specific enhancer in the human PDX-1 gene is regulated by hepatocyte nuclear factor $3 \beta$ (HNF-3 $\beta$ ), HNF-1 $\alpha$, and SPs transcription factors. J Biol Chem 276:17533-17540

45. Scarim AL, Arnush M, Blair LA et al. (2001) Mechanisms of beta cell death in response to double-stranded (ds)RNA and interferon- $\gamma$ : dsRNA-dependent protein kinase apoptosis and nitric oxide-dependent necrosis. Am J Pathol 159: 273-283
46. Doyle SE, Vaidya SA, O'Connell R et al. (2002) IRF3 mediates a TLR3/TLR4-specific antiviral gene program. Immunity 17:251-263

47. Harding HP, Novoa I, Zhang Y et al. (2000) Regulated translation initiation controls stress-induced gene expression in mammalian cells. Mol Cell 6:1099-1108

48. Zinszner H, Kuroda M, Wang X et al. (1998) CHOP is implicated in programmed cell death in response to impaired function of the endoplasmic reticulum. Genes Dev 12:982995

49. Kaufman RJ (1999) Double-stranded RNA-activated protein kinase mediates virus-induced apoptosis: a new role for an old actor. Proc Natl Acad Sci USA 96:1169311695

50. Heitmeier MR, Scarim AL, Corbett JA (1998) Doublestranded RNA-induced inducible nitric-oxide synthase expression and interleukin-1 release by murine macrophages requires NF- $\mathrm{\kappa B}$ activation. J Biol Chem 273:15301-15307

51. Darville MI, Eizirik DL (1998) Regulation by cytokines of the inducible nitric oxide synthase promoter in insulin-producing cells. Diabetologia 41:1101-1108

52. Darville MI, Ho YS, Eizirik DL (2000) NF-KB is required for cytokine-induced manganese superoxide dismutase expression in insulin-producing cells. Endocrinology 141: 153-162

53. Zhang L, Pagano JS (2002) Structure and function of IRF-7. J Interferon Cytokine Res. 22:95-101

54. Barnes B, Lubyova B, Pitha PM (2002) On the role of IRF in host defense. J Interferon Cytokine Res 22:59-71

55. Andrews HN, Mullan PB, McWilliams S et al. (2002) BRCA1 regulates the interferon $\gamma$-mediated apoptotic response. J Biol Chem 277:26225-26232

56. Genin P, Algarte M, Roof P, Lin R, Hiscott J (2000) Regulation of RANTES chemokine gene expression requires cooperativity between NF- $\kappa \mathrm{B}$ and IFN-regulatory factor transcription factors. J Immunol 164:5352-5361

57. Alexopoulou L, Holt AC, Medzhitov R, Flavell RA (2001) Recognition of double-stranded RNA and activation of NF- $\kappa B$ by Toll-like receptor 3. Nature 413:732-738

58. Giannoukakis N, Rudert WA, Trucco M, Robbins PD (2000) Protection of human islets from the effects of interleukin-1 $\beta$ by adenoviral gene transfer of an IKB repressor. J Biol Chem 275:36509-36513

59. Heimberg H, Heremans Y, Jobin C et al. (2001) Inhibition of cytokine-induced NF- $\mathrm{KB}$ activation by adenovirus-mediated expression of a NF- $\mathrm{\kappa B}$ super-repressor prevents $\beta$-cell apoptosis. Diabetes 50:2219-2224

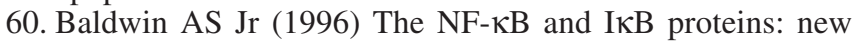
discoveries and insights. Annu Rev Immunol 14:649-683

61. Azevedo-Martins AK, Lortz S, Lenzen S, Curi R, Eizirik DL, Tiedge M (2003) Improvement of the mitochondrial antioxidant defense status prevents cytokine-induced nuclear factor- $\mathrm{\kappa B}$ activation in insulin-producing cells. Diabetes 52:93-101

62. Tiedge M, Lortz S, Munday R, Lenzen S (1999) Protection against the co-operative toxicity of nitric oxide and oxygen free radicals by overexpression of antioxidant enzymes in bioengineered insulin-producing RINm5F cells. Diabetologia 42:849-855

63. Karin M (1999) How NF-KB is activated: the role of the IкB kinase (IKK) complex. Oncogene 18:6867-6874

64. Stark GR, Kerr GM, Williams BR, Silvreman RH, Schreiber RD (1998) How cells respond to interferons. Annu Rev Biochem 67:227-264

65. Levin D, London IM (1978) Activation by double-stranded RNA of a protein kinase that phosphorylates eukariotic initiation factor 2. Proc Natl Acad Sci USA 75:1121-1125 
66. Novoa I, Zhang Y, Zeng H, Jungreis R, Harding HP, Ron D (2003) Stress-induced gene expression requires programmed recovery from translational repression. EMBO J 22:1180-1187

67. Oyadomari S, Araki E, Mori M (2002) Endoplasmic reticulum stress-mediated apoptosis in pancreatic $\beta$-cells. Apoptosis 7:335-345

68. Cardozo AK, Proost P, Gysemans C, Chen MC, Mathieu C, Eizirik DL (2003) IL-1 $\beta$ and IFN- $\gamma$ induce the expression of diverse chemokines and IL-15 in human and rat pancreatic islet cells, and in islets from pre-diabetic NOD mice. Diabetologia 46:255-266

69. Borner C (2003) The Bcl-2 protein family: sensors and checkpoints for life-or-death decisions. Mol Immunol 39: 615-647

70. Friedlander RM (2003) Apoptosis and caspases in neurodegenerative diseases. N Engl J Med 348:1365-1375

71. Newmeyer DD, Ferguson-Miller S (2003) Mitochondria: releasing power for life and unleashing the machineries of death. Cell 112:481-490

72. Mitchell KO, Ricci MS, Miyashita T et al. (2000) Bax is a transcriptional target and mediator of c-myc-induced apoptosis. Cancer Res 60:6318-6325

73. Lassus P, Opitz-Araya X, Lazebnik Y (2002) Requirement for caspase-2 in stress-induced apoptosis before mitochondrial permeabilization. Science 297:1352-1354

74. Edlund H (2001) Factors controlling pancreatic cell differentiation and function. Diabetologia. 44:1071-1079

75. Kaneto H, Sharma A, Suzuma K et al. (2002) Induction of c-Myc expression suppresses insulin gene transcription by inhibiting NeuroD/BETA2-mediated transcriptional activation. J Biol Chem 277:12998-13006

76. Heremans Y, Van De Casteele M, in't Veld P et al. (2002) Recapitulation of embryonic neuroendocrine differentiation in adult human pancreatic duct cells expressing neurogenin 3. J Cell Biol 159:303-312

77. Artavanis-Tsakonas S, Rand MD, Lake RJ (1999) Notch signalling: cell fate control and signal integration in development. Science 284:770-776

78. Kim SK, Hebrok M (2001) Intercellular signals regulating pancreas development and function. Genes Dev 15:111-127
79. Guidotti LG, Chisari FV (2001) Noncytolytic control of viral infections by the innate and adaptive immune response. Annu Rev Immunol 19:65-91

80. Janeway CA Jr (2001) How the immune system works to protect the host from infection: a personal view. Proc Natl Acad sci USA 98:7461-7468

81. Arnheiter H, Frese M, Kambadur R, Meier E, Haller O (1996) Mx transgenic mice-animal models of health. Curr Top Microbiol Immunol 206:119-147

82. Bass BL (1997) RNA editing and hypermutation by adenosine deamination. Trends Biochem Sci 22:157-162

83. Justesen J, Hartmann R, Kjeldgaard NO (2000) Gene structure and function of the $2^{\prime}, 5^{\prime}$-oligoadenylate synthetase family. Cell Mol Life Sci 57:1593-1612

84. Chen MC, Proost P, Gysemans C, Mathieu C, Eizirik DL (2001) Monocyte chemoattractant protein-1 is expressed in pancreatic islets from prediabetic NOD mice and in interleukin-1 $\beta$-exposed human and rat islet cells. Diabetologia 44:325-332

85. Frigerio S, Junt T, Lu B et al. (2002) Beta cells are responsible for CXCR3-mediated T-cell infiltration in insulitis. Nat Med 8:1414-1420

86. Schall TJ, Bacon K, Toy KJ, Goeddel DV (1990) Selective attraction of monocytes and T lymphocytes of the memory phenotype by the cytokine RANTES. Nature 347:669-671

87. Godiska R, Chantry D, Dietsch GN, Gray PW (1995) Chemokine expression in murine experimental allergic encephalomyelitis. J Neuroimmunol 58:167-176

88. Miyagishi R, Kikuchi S, Takayama C, Inoue Y, Tashiro K (1997) Identification of cell types producing RANTES, MIP- $1 \alpha$ and MIP-1 $\beta$ in rat experimental autoimmune encephalomyelitis by in situ hybridization. J Neuroimmunol 77:17-26

89. Bradley LM, Asensio VC, Schioetz LK et al. (1999) Isletspecific Th1, but not Th2, cells secrete multiple chemokines and promote rapid induction of autoimmune diabetes. J Immunol 162:2511-2520

90. Geiss G, Jin G, Guo J, Bumgarner R, Katze MG, Sen GC (2001) A comprehensive view of regulation of gene expression by double-stranded RNA-mediated cell signaling. J Biol Chem. 276:30178-30182 